\title{
KONSERVASI BURUNG GOSONG MALUKU (Eulipoa wallacei) BERBASIS MASYARAKAT DI DESA SIMAU, KECAMATAN GALELA
}

\author{
COMMUNITY BASED GOSONG MALUKU (Eulipoa wallacei) BIRDS \\ IN THE VILLAGE OF SIMAU, GALELA SUB DISTRICT
}

\author{
${ }^{(1)}$ Ronald Kondo Lembang, ${ }^{(2)}$ Sunarno, ${ }^{(3)}$ O.F.W. Tutupary, ${ }^{(4)}$ B.R.Toisutta, ${ }^{(5)}$ Bayu Sadjab \\ Fakultas Ilmu Alam dan Teknologi Rekayasa, Universitas Halmahera \\ Kampus UNIERA Kompleks GMIH, Wari Ino Tobelo, Halmahera Utara, 97762 \\ Penulis Korespondensi Email : klronald4@gmail.com \\ \begin{tabular}{l|l} 
Diterima: 10 April 2018 & Disetujui: 3 Mei 2018
\end{tabular}
}

\begin{abstract}
Abstrak
Desa Simau, Kecamatan Galela merupakan salah satu tempat yang menjadi habitat bertelur Gosong Maluku (Eulipoa wallacei) atau dalam bahasa lokal disebut Mamoa yang terbesar di Maluku Utara. Burung ini merupakan salah satu jenis endemik wilayah Maluku dan Maluku Utara dan telah dilindungi oleh peraturan perundang-undangan. Ancaman terbesar terhadap burung ini adalah pengambilan telur oleh masyarakat untuk diperdagangkan. Upaya konservasi terhadap burung Gosong Maluku ini telah dilakukan oleh masyarakat Desa Simau dengan cara-cara yang tradisional sebagai bentuk kesadaran terhadap pentingnya habitat dan satwa endemik ini. Penelitian ini bertujuan untuk mengkaji dan mendokumentasikan teknik konservasi terhadap burung Gosong Maluku (Eulipoa wallacei) yang dilakukan oleh masyarakat Desa Simau. Metode yang digunakan dalam penelitian ini adalah dengan wawancara, observasi lapangan dan dianalisis dengan metode deskriptif kualitatif. Hasil penelitian menunjukkan bentuk - bentuk konservasi berbasis masyarakat terhadap satwa burung Gosong Maluku (Eulipoa wallacei) meliputi pengetahuan lokal teknik pengambilan telur yang memperhatikan prinsip kelestarian, teknik konservasi in situ yaitu cara pengeraman telur berdasarkan pengetahuan lokal masyarakat dengan tahapan penggalian lubang telur, penanaman telur, dan penimbunan telur. Konsep konservasi terhadap burung Gosong Maluku ini masih dipraktekkan sampai sekarang oleh masyarakat dan dapat dijadikan sebagai model atau contoh konservasi berbasis masyarakat lokal.
\end{abstract}

Kata Kunci : Gosong Maluku, konservasi, masyarakat, kearifan lokal

\begin{abstract}
Simau Village, Galela Subdistrict is one of the habitats for Maluku Gosong (Eulipoa wallacei) or in the local language called Mamoa, the largest in North Maluku. This bird is one of the endemic species in Maluku and North Maluku and has been protected by legislation. The biggest threat to this bird is taking eggs by the community to trade. The conservation efforts of the Maluku Gosong bird have been carried out by the people of Simau Village in traditional ways as a form of awareness of the importance of this endemic habitat and animals. This study aims to examine and document the conservation techniques of the Maluku Gosong (Eulipoa wallacei) bird carried out by the Simau Village community. The method used in this study was interviews, field observations and analyzed with qualitative descriptive methods. The results showed that forms of community-based conservation of the Maluku Gosong bird (Eulipoa wallacei) include local knowledge of egg retrieval techniques that pay attention to the principle of sustainability, in situ conservation techniques, namely how to incubate eggs based on local knowledge of the community by digging egg holes, planting eggs, and stockpiling of eggs. The conservation concept of Gosong Maluku birds is still practiced until now by the community and can be used as a model or example of local community-based conservation.
\end{abstract}

Keywords : Gosong Maluku, Conservation, community, local wisdom

DOI: 10.30598/jhppk/2018.2.2.195

ISSN ONLINE: 2621-8798

Page 195 


\section{PENDAHULUAN}

Burung Mamoa (Eulipoa wallacei) atau Gosong Maluku merupakan jenis burung dari genus Megapodidae adalah burung endemik Indonesia di Kepulauan Maluku penyebaran burung Mamoa yaitu pulau Halmahera, Ternate, Buru, Seram, Ambon, Haruku dan Misol (Andrew 1992; Coates dan Bishops, 2000). Burung Gosong Maluku (Eulipoa wallacei) atau dikenal sebagai Mamoa adalah salah satu spesies megapoda yang memiliki berat tubuh yang kecil jika dibandingkan 22 spesies megapoda. Status populasi burung ini sudah dilindungi berdasarkan Peraturan Menteri Lingkungan Hidup dan Kehutanan Nomor P.20/MENLHK/SETJEN/KUM.1/6/2018 tentang Jenis Tumbuhan dan Satwa Yang Dilindungi

Pulau Halmahera merupakan salah satu daerah di Maluku Utara yang menjadi habitat bertelur dari burung Gosong Maluku atau Mamoa ini, tepatnya di Kabupaten Halmahera Utara berada di Kecamatan Galela, Desa Simau dan Desa Limau. Burung Gosong Maluku pada saat ini mengalami ancaman yang cukup besar yaitu adanya pemanfaatan dan pengambilan telur oleh masyarakat untuk diperjualbelikan serta adanya konversi lahan menjadi lahan pertanian yang mengakibatkan terjadinya penurunan populasi dialam.

Upaya pendekatan konservasi yang kolaboratif dan partisipatif merupakan alternatif untuk menjawab tantangan upaya pelestarian dan konservasi satwa endemik. Hal ini berdasarkan asumsi bahwa masyarakat lokal memiliki kepentingan dan keterkaitan dengan sumberdaya alam di sekitarnya sehingga penting masyarakat lokal dilibatkan. Nilai - nilai pengetahuan lokal tentang konservasi seringkali dilakukan oleh masyarakat namun belum banyak didokumentasikan sehingga diharapkan adanya model-model konservasi berbasis masyarakat dapat menjadi jalan keluar melestarikan keanekaragaman hayati di setiap wilayah di Indonesia.

Desa Simau, sebagai salah satu tempat habitat bertelur burung Gosong Maluku (Eulipoa wallacei) memiliki praktek-praktek konservasi terhadap kelestarian salah satu jenis satwa endemik tersebut. Selama ini pemanfaatan telur oleh masyarakat Simau disebabkan karena motif ekonomi namun dalam praktek pemanfaatan tersebut, secara tidak sengaja telah mempraktekkan prinsip konservasi.

Berdasarkan latar belakang tersebut, penelitian ini bertujuan untuk mengkaji dan mendokumentasikan bentuk-bentuk konservasi terhadap burung Gosong Maluku (Eulipoa wallacei) berbasis masyarakat di Desa Simau.

\section{METODE PENELITIAN}

Metode yang digunakan dalam penelitian ini adalah metode deskriptif kualitatif. Penelitian kualitatif merupakan penelitian yang mengambil fakta berdasarkan pemahaman subyek penelitian, mengetengahkan hasil pengamatan itu secara sangat rinci (Agusta, 1998). 
Pengumpulan data melalui teknik wawancara terstruktur dengan teknik snowball, pengamatan berperan serta terbatas, penelusuran data sekunder yang berhubungan dengan objek penelitian terutama para pengambil telur. Tahapan analisis yang dilakukan oleh peneliti adalah membuat daftar pertanyaan wawancara, pengumpulan data dan analisis data yang dilakukan oleh peneliti sendiri.

Untuk mengetahui sejauh mana informasi yang diberikan oleh masyarakat tentang objek penelitian, maka peneliti melakukan beberapa tahapan :

1. Menyusun daftar pertanyaan wawancara berdasarkan dari unsur-unsur kredibilitas yang akan ditanyakan pada narasumber atau informan

2. Melakukan wawancara dengan masyarakat terutama para pengambil telur burung Gosong Maluku (Eulipoa wallacei) tentang perilaku konservasi yang dilakukan oleh masyarakat Desa Simau

3. Melakukan dokumentasi langsung dilapangan yang berhubungan dengan objek penelitian

4. Melakukan analisis terhadap data yang diperoleh baik data wawancara maupun data pengamatan dilapangan

\section{HASIL DAN PEMBAHASAN}

Habitat bertelur burung Gosong Maluku (Eulipoa wallacei) atau disebut Mamoa di Desa Simau berdasarkan hasil pemetaan partisipatif memiliki luas sebesar $50.813,8 \mathrm{~m}^{2}$ yang tersebar dari Kali Hela sampai Kali Denamabobane pada pesisir pantai Desa Simau. Lokasi habitat bertelur ini dikelola oleh masyarakat yang diklaim sebagai wilayah milik mereka secara histori, dan masyarakat tersebut yang juga berprofesi sebagai pengambil telur

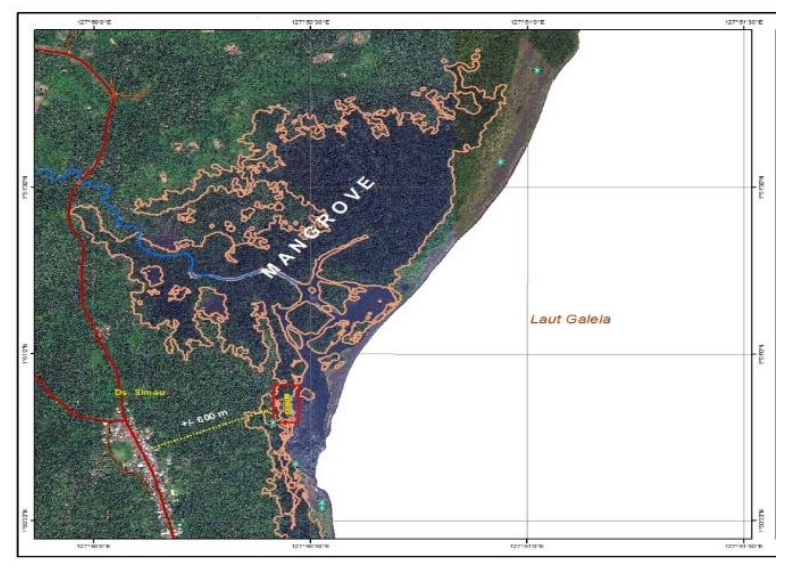

\section{Gambar 1. Peta Lokasi Habitat Bertelur Gosong Maluku di Simau, Galela}

\section{Teknik Pengambilan Telur Oleh Masyarakat Desa Simau}

Salah satu penyebab menurunnya populasi burung Gosong Maluku (Eulipoa wallacei) dialam adalah perburuan telur burung secara massif dilakukan oleh masyarakat. Telur burung Gosong Maluku diperjualbelikan dengan kisaran harga Rp. $10.000-15.000 /$ butir.

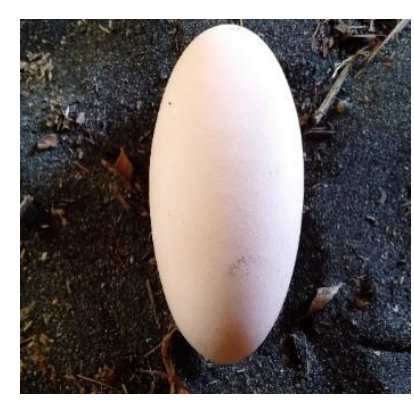

(1)

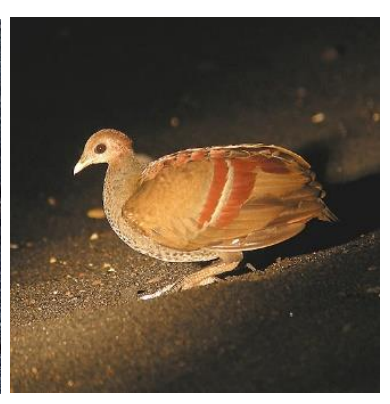

(2)
Gambar 2. (1) Telur Burung Gosong Maluku; (2) Burung Gosong Maluku 
Berdasarkan hasil wawancara dan pengamatan dilapangan, bahwa dalam berburu telur burung Gosong Maluku (Eulipoa wallacei), masyarakat Desa Simau memiliki teknik atau cara tertentu tanpa harus merusak habitat bertelur, dan pengetahuan ini sudah dipraktekkan turun temurun oleh masyarakat.
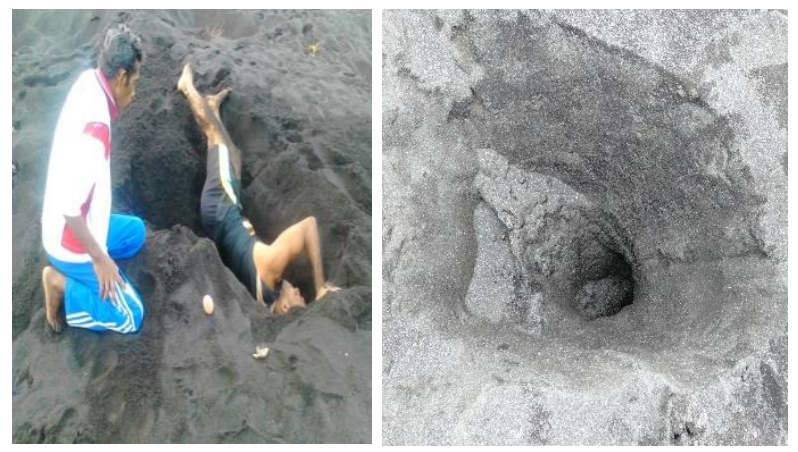

\section{Gambar 3. Teknik Pengambilan Telur Burung Gosong Maluku dan Bekas Lubang Telur}

Burung Gosong Maluku (Eulipoa wallacei) dalam meletakkan telur, terlebih dahulu melakukan penggalian lubang pada pasir sampai kedalaman tertentu kemudian meletakkan telurnya dan waktu bertelur pada malam hari. Masyarakat yang melakukan perburuan telur burung Gosong Maluku memiliki pengetahuan tersendiri untuk mengidentifikasi posisi telur dalam pasir kemudian baru melakukan penggalian. Jadi teknik berburu yang dilakukan adalah hanya menggali pada lubang galian yang diyakini terdapat telur, jadi tidak membongkar secara masif seluruh habitat

Kemudian dalam proses penggalian telur, kebanyakan telur yang sudah berumur 3-4 hari dalam pasir, sengaja dibiarkan untuk menetas sedangkan yang diambil adalah telur yang masih baru. Cara masyarakat mengidentifikasi lokasi atau sarang telur burung Gosong Maluku adalah dengan penampakan fisik dilokasi bertelur :

1. Adanya jejak kaki burung Gosong Maluku yang mengarah pada lubang tertentu dan terdapat bekas timbunan pasir yang menutupi lubang/sarang telur

2. Telur yang letaknya agak dangkal kedalamannya, terdapat gundukan pasir yang lebih tinggi dari permukaan pasir yang ada pada lokasi

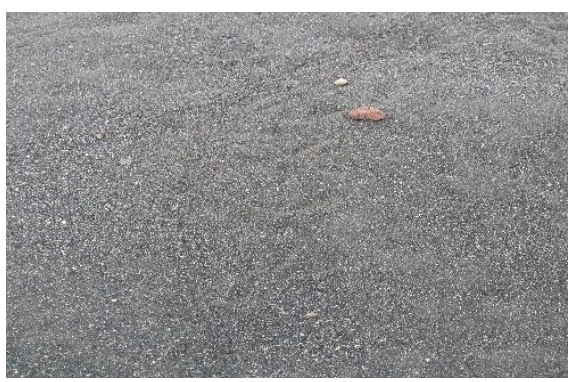

\section{Gambar 4. Jejak Kaki Burung Gosong Maluku}

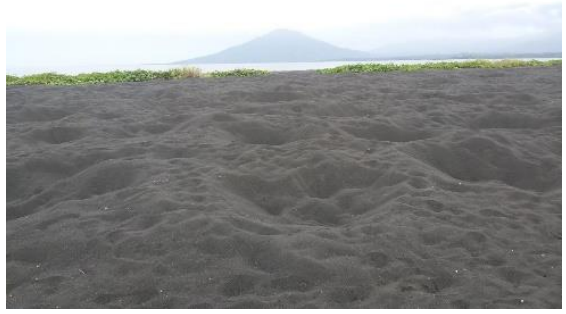

\section{Gambar 5. Sarang Telur Burung Gosong Maluku}

Teknik Penetasan dan Pengeraman Telur Burung Gosong Maluku oleh Masyarakat Simau

Upaya pelestarian burung Gosong Maluku (Eulipoa wallacei) telah dilakukan masyarakat 
Desa Simau melalui kegiatan pengeraman telur pada habitat bertelur. Berdasarkan pengamatan dilapangan, tahapan kegiatan penetasan dan pengeraman telur burung Gosong Maluku meliputi

\section{Penggalian Lubang Penetasan}

Proses penggalian lubang pengeraman ini, berdasarkan kedalaman lubang telur yang biasa ditemukan oleh pengambil telur, kedalaman telur dilokasi tersebut berkisar dari $60-80 \mathrm{~cm}$ tergantung pada bulan. Kedalaman lubang sarang telur selain dipengaruhi oleh temperatur juga di pengaruhi oleh bulan gelap dan bulan terang pada bulan terang lebih dalam sedangkan bulan gelap tidak sedalam bulan terang (Sjafani, 2006). Kedalaman telur yang digali oleh masyarakat dalam proses adalah berada pada kisaran $60-70 \mathrm{~cm}$ seperti pada Gambar 6.
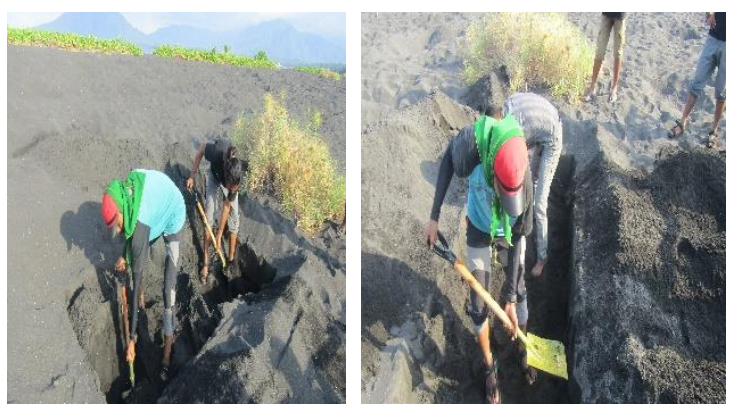

Gambar 6. Proses Penggalian Lubang Pengeraman Telur Burung Gosong Maluku

2. Proses Penanaman Telur

Tahapan selanjutnya adalah mengatur dan meletakkan telur burung Gosong Maluku pada lubang yang digali. Jarak antara telur berkisar $20-25 \mathrm{~cm}$, dalam peletakkan telur juga tidak boleh salah posisinya, bagian telur yang diletakkan secara vertikal, bagian telur yang runcing itu diletakkan bagian bawah.

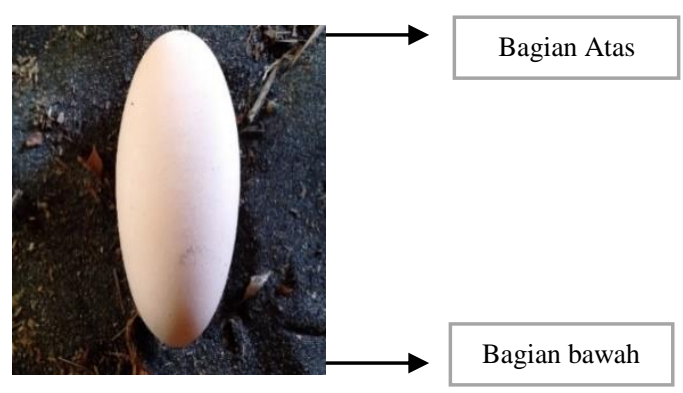

Gambar 7. Posisi Telur yang Ditanam

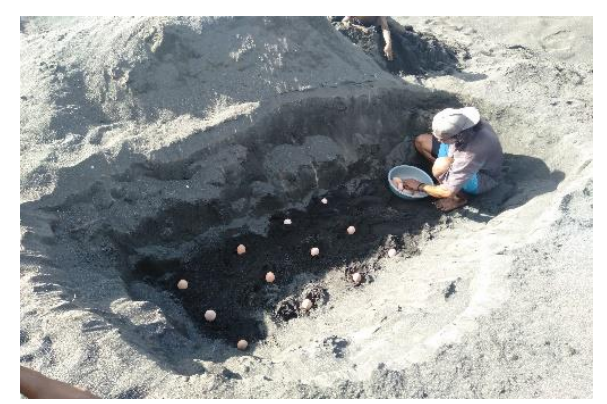

\section{Gambar 8. Cara Meletakkan Telur Burung Gosong Maluku}

3. Tahapan Penimbunan Telur

Proses terakhir dalam kegiatan pengeraman telur ini adalah penimbunan telur. Telur - telur yang telah diletakkan dalam lubang kemudian ditimbun kembali dengan pasir hasil galian.

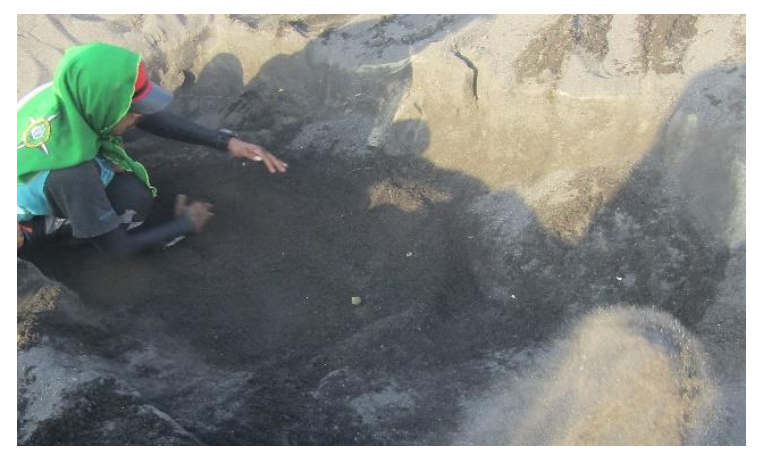

Gambar 9. Proses Penimbunan Telur Burung Gosong Maluku 
Berdasarkan hasil pengamatan dilapangan, masa inkubasi yang dibutuhkan oleh burung Gosong Maluku (Eulipoa wallacei) adalah berkisar 70 90 hari sejak pengeraman telur sampai menetas. Kegagalan penetasan biasanya dipengaruhi oleh beberapa faktor yaitu :

1. Adanya predator yang memangsa anakan burung seperti tikus

2. Anakan burung yang tertimbun oleh pasir yang runtuh

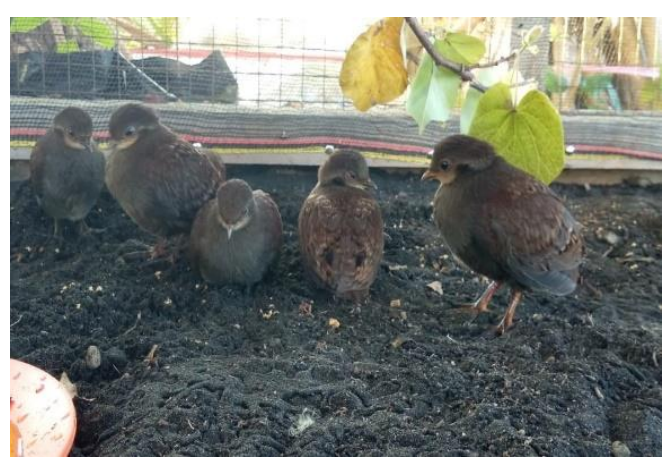

\section{Gambar 10. Anakan Burung Mamoa yang telah menetas}

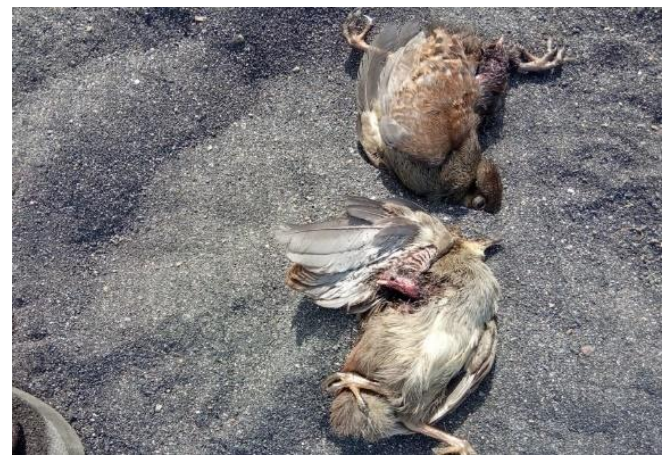

\section{Gambar 11. Anakan Burung Mamoa dimangsa oleh predator tikus}

\section{KESIMPULAN}

Kesimpulan yang dapat diperoleh dari hasil penelitian ini adalah :

1. Bentuk konservasi berbasis masyarakat di Desa Simau dalam melestarikan burung Gosong Maluku yaitu pengambilan telur dengan menganut prinsip-prinsip konservasi, melakukan kegiatan pengeraman dan penetasan telur secara tradisional

2. Masyarakat memiliki pengetahuan lokal tentang identifikasi keberadaan telur dan cara meletakkan telur dalam proses pengeraman.

\section{DAFTAR PUSTAKA}

Andrew P. 1992. The Bird of Indonesia. A Chicklist (Peters sequence). Kukila checklist no 1. Indonesia Ornithology Jakarta.

Coates BJ, KD Bishop. 2000. Panduan Lapangan Burung-Burung di Kawasan Wallace. Sulawesi, Maluku dan Nusa Tenggara. BirdLife Internasional-Indonesia Bogor.

Peraturan Menteri Lingkungan Hidup dan Kehutanan Republik Indonesia Nomor P.20/MENLHK/SETJEN/KUM.1/6/2018 tentang Jenis Tumbuhan dan Satwa Yang Dilindungi

Nur Sjafani, 2006. Kajian Perkembangbiakan Burung Mamoa (Eulipoa wallacei) di Kecamatan Galela Kabupaten Halmahera Utara. Tesis. Pascasarjana Institut Pertanian Bogor. 